\title{
Commentary
}

\section{One hundred fifty years without Darwin are enough!}

\author{
Francisco J. Ayala ${ }^{1}$ \\ University of California, Irvine, California 92697, USA
}

Charles Darwin (1809-1882) was born two centuries ago. The Origin of Species was published in 1859, $150 \mathrm{yr}$ ago. The theory of biological evolution by natural selection, as first proposed by Darwin, is the central organizing principle of biology. Indeed, as the great evolutionist Theodosius Dobzhansky asserted in 1973 in an address to the American Association of Biology Teachers, "Nothing in biology makes sense except in the light of evolution" (Dobzhansky 1973). Yet, in the United States, evolution is not generally accepted by the public.

According to a Gallup poll of 1016 U.S. adults, taken in November 2004, $45 \%$ of those surveyed favored the statement that "God created human beings in their present form within the last 10,000 years," 38\% favored that "Man developed over millions of years, but God guided the process," and 13\% that "Man developed over millions of years from less advanced life forms." Teaching creationism rather than evolution in the schools is favored by a large number of American citizens. In a CNN/USA Today Gallup poll of 1001 adults conducted in March 2005, 76\% would not "be upset if public schools in [their] community taught creationism," but only 63\% would not "be upset if the schools taught evolution." Only $22 \%$ would be upset if creationism would be taught, while $34 \%$ would be upset if evolution would be taught. Other polls yield similar statistics.

In 1959, at a symposium celebrating the 100th anniversary of the publication of the Origin of Species, the eminent geneticist and Nobel Laureate H.J. Muller proclaimed "One Hundred Years without Darwin Are Enough!" (Muller 1959). Fifty years later, Darwin's theory of evolution is far from universally accepted by the American public and activists throughout the country are advancing creationist or "intelligent design" alternatives to explain the origin, diversity, and adaptation of organisms, seeking that these "theories" be taught in the schools. Our educational system and society as a whole are best served when we teach science, not religious faith masquerading as science, in the classrooms. It is pathetic that at this point in history we need to proclaim that 150 years without Darwin's Origin of Species are enough.

\section{Darwin's scientific revolution}

Darwin occupies an exalted place in the history of Western thought, deservedly receiving credit for the theory of evolution. In The Origin of Species, he laid out the evidence demonstrating the evolution of organisms. Darwin did not use the term "evolution," which did not have its current meaning, but referred to the evolution of organisms by the phrase "common descent with modification" and similar expressions. However, Darwin accomplished something much more important for intellectual history than demonstrating evolution. Indeed, accumulating evidence for common descent with diversification may very well have been a subsidiary objective of Darwin's masterpiece. Darwin's Origin of Species is, first and foremost, a sustained argument to solve the problem of how to account scientifically for the design of organ-

'Corresponding author.

E-mail fjayala@uci.edu; fax (949) 824-2474.

Article is online at http://www.genome.org/cgi/doi/10.1101/gr.084285.108. isms. Darwin seeks to explain the design of organisms, their complexity, diversity, and marvelous contrivances as the result of natural processes. Darwin brings about the evidence for evolution because evolution is a necessary consequence of his theory of design. The design of organisms remains a subject of active research up to the present. On December 1-2, 2006, the U.S. National Academy of Sciences sponsored a symposium on "Adaptation and Complex Design." The papers presented at the symposium were published in the Proceedings of the National Academy of Sciences (2007, http://www.pnas.org/content/104/suppl.1), as well as in a book with the same title (Avise and Ayala 2007).

There is a version of the history of the ideas that sees a parallel between the Copernican and the Darwinian revolutions. In this view, the Copernican Revolution consisted in displacing the Earth from its previously accepted locus as the center of the universe, moving it to a subordinate place as just one more planet revolving around the Sun. In congruous manner, the Darwinian Revolution is viewed as consisting of the displacement of humans from their exalted position as the center of life on Earth, with all other species created for the service of humankind. According to this version of intellectual history, Copernicus had accomplished his revolution with the heliocentric theory of the solar system. Darwin's achievement emerged from his theory of organic evolution. Sigmund Freud (Adler 1952) refers to these two revolutions as "outrages" inflicted upon humankind's self-image and adds a third one, his own: "Humanity in the course of time had to endure from the hands of science two great outrages upon its naïve self-love. The first was when it realized that our earth was not the centre of the universe, but only a tiny speck in a world-system of a magnitude hardly conceivable; this is associated in our minds with the name of Copernicus, although Alexandrian doctrines taught something very similar. The second was when biological research robbed man of his peculiar privilege of having been specially created, and relegated him to a descent from the animal world, implying an ineradicable animal nature in him: this transvaluation has been accomplished in our own time upon the instigation of Charles Darwin, Wallace, and their predecessors, and not without the most violent opposition from their contemporaries. The third and most bitter blow upon man's craving for grandiosity" was meted out in the 20th Century by psychoanalysis, revealing that man's ego "is not even master in his own house."

What the standard version of the Copernican and Darwinian version of the two revolutions says is correct but inadequate, because it misses what is most important about these two intellectual revolutions, namely that they ushered in the beginning of science in the modern sense of the word. These two revolutions may jointly be seen as the one Scientific Revolution, with two stages, the Copernican and the Darwinian.

The Copernican Revolution was launched with the publication in 1543, the year of Nicolaus Copernicus' death, of his De revolutionibus orbium celestium (On the Revolutions of the Celestial Spheres), and bloomed with the publication in 1687 of Isaac Newton's Philosophiae naturalis principia mathematica (The Mathematical Principles of Natural Philosophy). The discoveries by Copernicus, Kepler, Galileo, Newton, and others, in the 16th and 
17th Centuries, had gradually ushered in a conception of the universe as matter in motion governed by natural laws. It was shown that Earth is not the center of the universe, but a small planet rotating around an average star; that the universe is immense in space and in time; and that the motions of the planets around the Sun can be explained by the same simple laws that account for the motion of physical objects on our planet. Laws such as $f=m \times a$ (force $=$ mass $\times$ acceleration); or the inversesquare law of attraction, $f=g\left(m_{1} m_{2}\right) / r^{2}$ (the force of attraction between two bodies is directly proportional to their masses, but inversely related to the square of the distance between them).

These and other discoveries greatly expanded human knowledge. The conceptual revolution they brought about was more fundamental yet: a commitment to the postulate that the universe obeys immanent laws that account for natural phenomena. The workings of the universe were brought into the realm of science: explanation through natural laws. All physical phenomena could be accounted for as long as the causes were adequately known.

The advances of physical science brought about by the Copernican Revolution had driven humankind's conception of the universe to a split-personality state of affairs, which persisted well into the mid-19th Century. Scientific explanations, derived from natural laws, dominated the world of nonliving matter, on the Earth as well as in the heavens. However, supernatural explanations, which depended on the unfathomable deeds of the Creator, were accepted as explanations of the origin and configuration of living creatures. Authors, such as William Paley, argued that the complex design of organisms could not have come about by chance, or by the mechanical laws of physics, chemistry, and astronomy, but was rather accomplished by an omniscient and omnipotent deity, just as the complexity of a watch, designed to tell time, was accomplished by an intelligent watchmaker.

It was Darwin's genius to resolve this conceptual schizophrenia. Darwin completed the Copernican Revolution by drawing out for biology the notion of nature as a lawful system of matter in motion that human reason can explain without recourse to supernatural agencies. The conundrum faced by Darwin can hardly be overestimated. The strength of the argument from design to demonstrate the role of the Creator had been forcefully set forth by philosophers and theologians. Wherever there is function or design, we look for its author. It was Darwin's greatest accomplishment to show that the complex organization and functionality of living beings can be explained as the result of a natural process-natural selection-without any need to resort to a Creator or other external agent. The origin and adaptations of organisms in their profusion and wondrous variations were thus brought into the realm of science (Ayala 2007).

\section{William Paley's argument-from-design}

The English clergyman and author William Paley (1743-1805) was intensely committed to the abolition of the slave trade and had become by the 1780s a much sought public lecturer against slavery. He was also an influential writer of works on Christian philosophy, ethics, and theology. The Principles of Moral and Political Philosophy (1785) and A View of the Evidence of Christianity (1794) earned him prestige and well-endowed ecclesiastical benefices, which allowed him a comfortable life. Illness forced him in 1800 to give up his public speaking career, which provided ample time to study science, particularly biology, and write Natural Theology; or, Evidences of the Existence and Attributes of the Deity (Paley 1802a), the book by which he would become best known to posterity and which would greatly influence Darwin. With Natural Theology, Paley sought to update John Ray's Wisdom of God Manifested in the Works of the Creation (1691), taking advantage of one century of additional scientific knowledge.

William Paley's Natural Theology is a sustained "argument from design" claiming that the living world provides compelling evidence of being designed by an omniscient and omnipotent Creator. The argument has two parts: first, that organisms give evidence of being designed; second, that only an omnipotent God could account for the perfection, multitude, and diversity of designs. Paley's keystone claim is that, "There cannot be design without a designer; contrivance, without a contriver; order, without choice; ... means suitable to an end, and executing their office in accomplishing that end, without the end ever having been contemplated." (Paley 1802b).

Paley elaborates the argument-from-design with greater cogency and more extensive knowledge of biological detail than it has ever been done by any other author, before or since. Paley brings in all sorts of biological knowledge, from the geographic distribution of species to the interactions between predators and their prey, the interactions between the sexes, the camel's stomach and the woodpecker's tong, the compound eyes of insects and the spider's web. He explores and rejects the possibility of a sort of "natural selection": organisms may have come about by chance in an endless multiplicity of forms; those now in existence are those that happened to be functionally organized because they are the only ones able to survive and reproduce. (Empedocles, the 5th Century BC philosopher of Classic Greece, had already speculated that living organisms arose as disjointed body parts-heads, trunks, and limbs-that combined at random, with only viable combinations surviving.) Paley's evidence for intelligent design and against chance derives from a notion that some contemporary authors have named "irreducible complexity," that he calls "relation": the presence of a great variety of parts interacting with each other to produce an effect, which cannot be accomplished if any of the parts are missing.

Paley's Natural Theology has chapters dedicated to the complex design of the human eye; to the human frame, which displays a precise mechanical arrangement of bones, cartilage, and joints; to the circulation of the blood and the disposition of blood vessels; to the comparative anatomy of humans and animals; to the digestive system, kidneys, urethras, and bladder; to the wings of birds and the fins of fish; and much more. For 352 pages, Natural Theology conveys Paley's expertise: extensive and accurate biological knowledge, as detailed and precise as it was available in the year 1800. After detailing the precise organization and exquisite functionality of each biological object or process, Paley draws again and again the same conclusion, that only an omniscient and omnipotent deity could account for these marvels of mechanical perfection, purpose, and functionality, and for the enormous diversity of inventions that they entail.

\section{Darwin's theory}

The discovery of natural selection, Darwin's awareness that it was a greatly significant discovery because it was science's answer to Paley's argument from design, and Darwin's designation of natural selection as "my theory" can be traced in Darwin's "Red Notebook" and "Transmutation Notebooks B to E," which he started in March 1837, not long after returning (on October 2, 1836) from his 5-yr voyage on the Beagle, and completed in late 1839 (see Eldredge 2005). Darwin considered natural selection, rather than

\section{Genome Research}


his demonstration of evolution, his most important discovery, and designated it as "my theory," a designation he never used when referring to the evolution of organisms.

The evolution of organisms was commonly accepted by naturalists in the middle decades of the 19th Century. The distribution of exotic species in South America, in the Galápagos Islands, and elsewhere, and the discovery of fossil remains of longextinguished animals, confirmed the reality of evolution in Darwin's mind. The intellectual challenge was to explain the origin of distinct species of organisms, how new ones adapted to their environments, that "mystery of mysteries," as it had been labeled by Darwin's older contemporary, the prominent scientist and philosopher Sir John Herschel (1792-1871).

Early in the Notebooks of 1837 to 1839 , Darwin registers his discovery of natural selection and repeatedly refers to it as "my theory." From then until his death in 1882, Darwin's life would be dedicated to substantiating natural selection and its companion postulates, mainly the pervasiveness of hereditary variation and the enormous fertility of organisms, which much surpassed the capacity of available resources. Natural selection became for Darwin "a theory by which to work." He relentlessly pursued observations and performed experiments in order to test the theory and resolve presumptive objections.

In his Autobiography, Darwin wrote, "The old argument of design in nature, as given by Paley, which formerly seemed to me so conclusive, falls, now that the law of natural selection has been discovered. We can no longer argue that, for instance, the beautiful hinge of a bivalve shell must have been made by an intelligent being, like the hinge of a door by a man" (Barlow 1958).

Darwin's focus in The Origin was the explanation of design, with evolution playing the subsidiary role of supporting evidence. The Introduction and chapters I-VIII of The Origin explain how natural selection accounts for the adaptations and behaviors of organisms, their "design." The extended argument starts in chapter I, where Darwin describes the successful selection of domestic plants and animals and, with considerable detail, the success of pigeon fanciers seeking exotic "sports." The success of plant and animal breeders manifests how much selection can accomplish by taking advantage of spontaneous variations that occur in organisms, but happen to fit the breeders' objectives. A sport (mutation) that first appears in an individual can be multiplied by selective breeding, so that after a few generations that sport becomes fixed in a breed, or "race." The familiar breeds of dogs, cattle, chickens, and food plants have been obtained by this process of selection practiced by people with particular objectives.

The ensuing chapters (II-VIII) of The Origin extend the argument to variations propagated by natural selection for the benefit of the organisms themselves, rather than by artificial selection of traits desired by humans. As a consequence of natural selection, organisms exhibit design, that is, exhibit adaptive organs and functions. The design of organisms as they exist in nature, however, is not "intelligent design," imposed by God as a Supreme Engineer or by humans; rather, it is the result of a natural process of selection, promoting the adaptation of organisms to their environments. This is how natural selection works: Individuals that have beneficial variations, that is, variations that improve their probability of survival and reproduction, leave more descendants than individuals of the same species that have less beneficial variations. The beneficial variations will consequently increase in frequency over the generations; less beneficial or harmful variations will be eliminated from the species. Eventually, all individuals of the species will have the beneficial features; new features will arise over eons of time.

Organisms exhibit complex design, but it is not, in current language, "irreducible complexity," emerging all of a sudden in full bloom. Rather, according to Darwin's theory of natural selection, the design has arisen gradually and cumulatively, step by step, promoted by the reproductive success of individuals with incrementally more adaptive elaborations.

It follows from Darwin's explanation of adaptation that evolution must necessarily occur as a consequence of organisms becoming adapted to different environments in different localities, and to the ever-changing conditions of the environment over time, and as hereditary variations become available at a particular time that improve, in that place and at that time, the organisms' chances of survival and reproduction. The Origin's evidence for biological evolution is central to Darwin's explanation of design, because this explanation implies that biological evolution occurs, which Darwin therefore seeks to demonstrate in most of the remainder of the book (Darwin 1859a).

In the concluding chapter XIV of The Origin, Darwin returns to the dominant theme of adaptation and design. In an eloquent final paragraph, Darwin asserts the "grandeur" of his vision: "It is interesting to contemplate an entangled bank, clothed with many plants of many kinds, with birds singing on the bushes, with various insects flitting about, and with worms crawling through the damp earth, and to reflect that these elaborately constructed forms, so different from each other, and dependent on each other in so complex a manner, have all been produced by laws acting around us... Thus, from the war of nature, from famine and death, the most exalted object, which we are capable of conceiving, namely, the production of the higher animals, directly follows. There is grandeur in this view of life, with its several powers, having been originally breathed into a few forms or into one; and that, whilst this planet has gone cycling on according to the fixed law of gravity, from so simple a beginning endless forms most beautiful and most wonderful have been, and are being, evolved" (Darwin 1859b; emphasis added).

\section{Natural selection}

Darwin's Origin addresses the same issue as Paley: how to account for the adaptive configuration of organisms and their parts, which are so obviously designed to fulfill certain functions. Darwin argues that hereditary adaptive variations ("variations useful in some way to each being") occasionally appear, and that these are likely to increase the reproductive chances of their carriers. The success of pigeon fanciers and animal breeders clearly shows the occasional occurrence of useful hereditary variations. In nature, over the generations, Darwin's argument continues, favorable variations will be preserved, multiplied, and conjoined; injurious ones will be eliminated.

Evolution affects all aspects of an organism's lifemorphology (form and structure), physiology (function), behavior, and ecology (interaction with the environment). Underlying these changes are changes in the hereditary materials. Hence, in genetic terms, evolution consists of changes in the organism's hereditary makeup.

Evolution can be seen as a two-step process. First, hereditary variation arises by mutation; second, selection occurs by which useful variations increase in frequency and those that are less useful or injurious are eliminated over the generations. "Useful" and "injurious" are terms used by Darwin in his definition of natural selection. The significant point is that individuals having 
useful variations "would have the best chance of surviving and procreating their kind" (Darwin 1859c). As a consequence, useful variations increase in frequency over the generations, at the expense of those that are less useful or injurious.

Natural selection is much more than a "purifying" process, for it is able to generate novelty by increasing the probability of otherwise extremely improbable genetic combinations. Natural selection in combination with mutation becomes, in this respect, a creative process. Moreover, it is a process that has been occurring for many millions of years, in many different evolutionary lineages and in a multitude of species, each consisting of a large number of individuals. Evolution by mutation and natural selection has produced the enormous diversity of the living world with its wondrous adaptations.

Natural selection is an incremental process, operating over time and yielding organisms better able to survive and reproduce than others. Individuals of a given species differ from one another at any one time only in small ways; for example, the difference between bacteria that have or lack an enzyme able to synthesize the sugar lactose or between moths that have light or dark wings. These differences typically involve one or only a few genes, but they can make the difference between survival or death, as in beneficial resistance to DDT or to antibiotics. Adaptations that involve complex structures, functions, or behaviors involve numerous genes.

Several hundred million generations separate modern animals from the early animals of the Cambrian geological period (542 million years ago). The number of mutations that can be tested, and those eventually selected, in millions of individual animals over millions of generations is difficult for a human mind to fathom, but we can readily understand that the accumulation of millions of small, functionally advantageous changes could yield remarkably complex and adaptive organs, such as the eye.

Natural selection produces combinations of genes that would seem highly improbable because natural selection proceeds stepwise over long periods of time. Consider the evolution of the eye in humans and other vertebrates. Perception of light, and later vision, were important for the survival and reproductive success of their ancestors, because sunlight is a predominant feature of the environment. Accordingly, natural selection favored genes and gene combinations that increased the functional efficiency of the eye. Such mutations gradually accumulated, eventually leading to the highly complex and efficient vertebrate eye.

\section{Evolutionary evidence: From Darwin to molecular biology}

Darwin and other 19th-Century biologists found compelling evidence for biological evolution in the comparative study of living organisms, in their geographic distribution, and in the fossil remains of extinct organisms. In The Origin of Species, Darwin dedicates five chapters to the evidence for evolution: two chapters to the geological record, or, as we are more likely to say nowadays, to paleontology; two chapters to biogeography; and one chapter to comparative anatomy and embryology. Since Darwin's time, the evidence from these sources has become stronger and more comprehensive, while biological disciplines that have emerged recently-genetics, biochemistry, ecology, animal behavior (ethology), neurobiology, and especially molecular biology—have supplied powerful additional evidence and detailed confirmation.

Darwin surely would have been pleased by the enormous accumulation of paleontological evidence, including the discov- ery of fossils of organisms intermediate between major groups, such as Archaeopteryx, intermediate between reptiles (dinosaurs) and birds, and Tiktaalik, intermediate between fish and tetrapods (Ahlberg and Clark 2006) and the numerous fossils and diverse species of hominins, intermediate between apes and Homo sapiens (e.g., Dalton 2006; White et al. 2006; Cela Conde and Ayala 2007). But there are good reasons to believe that Darwin would have been most pleased and most impressed with the overwhelming evidence for evolution and precise information about evolutionary history provided by molecular biology, a source of evidence and document of history that Darwin could not have even imagined.

Molecular biology, a discipline that emerged in the second half of the 20th Century, nearly $100 \mathrm{yr}$ after the publication of The Origin of Species, undoubtedly provides the strongest evidence yet of the evolution of organisms. Molecular biology proves evolution in two ways: first, by showing the unity of life in the nature of DNA and the workings of organisms at the level of enzymes and other protein molecules; second, and most important, by making it possible to reconstruct evolutionary relationships that were previously unknown, and to confirm, refine, and time all evolutionary relationships from the universal common ancestor up to all living organisms. The precision with which these events can be reconstructed is one reason why the evidence from molecular biology is so useful to evolutionists and so compelling.

DNA and proteins have been called "informational macromolecules" because they are long linear molecules made up of sequences of units-nucleotides or amino acids-that embody evolutionary information. Comparing the sequence of the components in two macromolecules establishes how many units are different. Because evolution usually occurs by changing one unit at a time, the number of differences is an indication of the recency of common ancestry. Thus, the inferences from paleontology, comparative anatomy, and other disciplines that study evolutionary history can be tested in molecular studies of DNA and proteins by examining the sequences of nucleotides and amino acids. The authority of this kind of test is overwhelming: each of the thousands of genes and thousands of proteins contained in an organism provides an independent test of that organism's evolutionary history.

Molecular evolutionary studies have three notable advantages over comparative anatomy and the other classical disciplines: precision, universality, and multiplicity. First, the information is readily quantifiable. The number of units that are different is easily established when the sequence of units is known for a given macromolecule in different organisms. It is simply a matter of aligning the units (nucleotides or amino acids) between two or more species and counting the differences. The second advantage, universality, is that comparisons can be made between very different sorts of organisms. There is very little that comparative anatomy can say when, for example, organisms as diverse as yeasts, pine trees, and human beings are compared, but there are numerous DNA and protein sequences that can be compared in all three. The third advantage is multiplicity. Each organism possesses thousands of genes and proteins, every one of which reflects the same evolutionary history. If the investigation of one particular gene or protein does not satisfactorily resolve the evolutionary relationship of a set of species, additional genes and proteins can be investigated until the matter has been settled.

The resourcefulness of molecular biology to study evolution can be noted in other ways as well. The widely different rates of evolution of different sets of genes opens up the opportunity for investigating different genes in order to achieve different degrees

\section{Genome Research}


of resolution in the tree of evolution. Evolutionists rely on slowly evolving genes for reconstructing remote evolutionary events, but increasingly faster evolving genes for reconstructing the evolutionary history of more recently diverged organisms.

Genes that encode ribosomal RNA molecules are among the slowest evolving genes. They have been used to reconstruct the evolutionary relationships among groups of organisms that diverged very long ago: for example, among bacteria, archaea, and eukaryotes (the three major divisions of the living world), which diverged more than 2 billion years ago, or among the protozoa compared with plants and with animals, groups of organisms that diverged about 1 billion years ago. Cytochrome $c$ evolves slowly, but not as slowly as the ribosomal RNA genes. Thus, it is used to decipher the relationships within large groups of organisms, such as among humans, fishes, and insects. Fast-evolving molecules, such as the fibrinopeptides involved in blood clotting, are appropriate for investigating the evolution of closely related animalsthe primates, for example, macaques, chimps, and humans.

It is now possible to make an assertion that would have delighted Darwin and would surely shock creationists and other antievolutionists, and perhaps startle many scientists and most of the general public: Gaps of knowledge in the evolutionary history of living organisms no longer need to exist. Molecular biology has made it possible to reconstruct the "universal tree of life," the continuity of succession from the original forms of life, ancestral to all living organisms, to every species now living on Earth. The main branches of the tree of life have been reconstructed on the whole and in great detail. More details about more and more branches of the universal tree of life are published in scores of scientific articles every month. The virtually unlimited evolutionary information encoded in the DNA sequence of living organisms allows evolutionists to reconstruct all evolutionary relationships leading to present-day organisms, with as much detail as wanted. Invest the necessary resources (time and laboratory expenses) and you can have the answer to any query, with as much precision as you want.

\section{Darwin and Wallace: An historical footnote}

Alfred Russell Wallace (1823-1913) is famously given credit for discovering, independently of Darwin, natural selection as the process accounting for the evolution of species. On June 18, 1858, Darwin wrote to Charles Lyell that he had received by mail a short essay from Wallace, such that "if Wallace had my [manuscript] sketch written in [1844] he could not have made a better abstract." Darwin and Wallace had started occasional correspondence in late 1855. At the time Wallace was in the Malay Archipelago collecting biological specimens. In his letters, Darwin would offer sympathy and encouragement to the occasionally dispirited Wallace for his "laborious undertaking." In 1858, Wallace came upon the idea of natural selection as the explanation for evolutionary change and he wanted to know Darwin's opinion about this hypothesis, since Wallace, as well as many others, knew that Darwin had been working on the subject for years, had shared his ideas with other scientists, and was considered by them as the eminent expert on issues concerning biological evolution.

Darwin was uncertain how to proceed about Wallace's letter. He wanted to credit Wallace's discovery of natural selection, but he did not want altogether to give up his own earlier independent discovery. Eventually, Sir Charles Lyell and Joseph Hooker proposed, with Darwin's consent, that Wallace's letter and two of Darwin's earlier writings would be presented at a meeting of the
Linnean Society of London. On July 1, 1858, three papers were read by the society's undersecretary, George Busk, in the order of their date of composition: Darwin's abbreviated abstract of his 230-page essay from 1844; an "abstract of abstract" that Darwin had written to the American botanist Asa Gray on September 5, 1857; and Wallace's essay, "On the Tendency of Varieties to Depart Indefinitely from Original Type; Instability of Varieties Supposed to Prove the Permanent Distinctness of Species" (Wallace 1858).

The meeting was attended by some 30 people, who did not include Darwin or Wallace. The papers generated little response and virtually no discussion, their significance apparently lost to those in attendance. Nor was it noticed by the president of the Linnean Society, Thomas Bell, who, in his annual address the following May, blandly stated that the past year had not been enlivened by "any of those striking discoveries which at once revolutionize" a branch of science.

Wallace's independent discovery of natural selection is remarkable. But the lesser credit given to Wallace than to Darwin for this discovery may not be misplaced. Wallace was not interested in explaining design, but rather in accounting for the evolution of species, as indicated in his paper's title: "On the Tendency of Varieties to Depart Indefinitely from the Original Type." Wallace thought that evolution proceeds indefinitely and is progressive. Wallace (1858) writes: "We believe that there is a tendency in nature to the continued progression of certain classes of varieties further and further from the original type-a progression to which there appears no reason to assign any definite limits. This progression, by minute steps, in various directions..."

Darwin, on the contrary, did not accept that evolution would necessarily represent progress or advancement, nor did he believe that evolution would always result in morphological change over time; rather, he knew of the existence of "living fossils," organisms that had remained unchanged for millions of years. For example, "some of the most ancient Silurian animals, as the Nautilus, Lingula, etc., do not differ much from living species" (Darwin 1859d). In 1858, Darwin was at work on a multivolume treatise, intended to be titled "On Natural Selection." Wallace's paper stimulated Darwin to write The Origin, which would be published the following year. Darwin saw The Origin as an abbreviated version of the much longer book he had planned to write.

\section{Intelligent design: The modern version}

William Paley was not the only proponent of the argument from design in Britain in the first half of the 19th Century. A few years after the publication of Natural Theology, the eighth Earl of Bridgewater endowed the publication of treatises that would set forth "the power, wisdom and goodness of God as manifested in the creation." Eight treatises were published during 1833-1840, several of which artfully incorporate the best science of the time and had considerable influence on the public and among scientists. William Buckland, professor of geology at Oxford University, notes in Geology and Mineralogy (1836) the world distribution of coal and mineral ores and proceeds to point out that they had been deposited in a remote part, yet obviously with the forethought of serving the larger human populations that would come about much later. Another geologist, Hugh Miller in The Testimony of the Rocks (1858), would argue that it is not only the perfection of design but also the beauty of natural structures found in rock formations and in mountains and rivers that manifests the intervention of the Creator. 
One of the Bridgewater treatises, The Hand, Its Mechanisms and Vital Endowments as Evincing Design, was written by Sir Charles Bell, a distinguished anatomist and surgeon, famous for his neurological discoveries, who became professor of surgery in 1836 at the University of Edinburgh. Bell follows Paley's manner of argument, examining in considerable detail the wondrously useful design of the human hand, but also the perfection of design of the forelimb used for different purposes in different animals, serving in each case the particular needs and habits of its owner: the human's arm for handling objects, the dog's leg for running, and the bird's wing for flying.

In the 1990s, several authors, notably biochemist Michael Behe (1996), theorist William Dembski (1995), and law professor Phillip Johnson (2000), among others, revived the argument from design. Often, however, these authors sought to hide their real agenda, and, thus, typically avoid explicit reference to God, so that the "theory" of intelligent design (ID) could be taught in the public schools, as an alternative to the theory of evolution, without incurring conflict with the U.S. Constitution, which forbids the endorsement of any religious beliefs in public institutions.

On December 20, 2005, after a five-week trial, John E. Jones III, federal judge for the Middle District of Pennsylvania, issued a 130-page-long decision (Kitzmiller v. Dover Area School District) declaring that "The overwhelming evidence at trial established that ID [intelligent design] is a religious view, a mere relabeling of creationism, and not a scientific theory ... ID is not supported by any peer-reviewed research, data, or publications."

\section{Design, chance, and necessity}

An engineer has a preconception of what the design of a contrivance or structure is supposed to achieve, and will select suitable materials and arrange them in a preconceived manner so that it fulfills the intended function. On the contrary, natural selection has no foresight, nor does it operate according to some preconceived plan. Rather it is a purely natural process resulting from the interacting properties of physicochemical and biological entities. Natural selection is simply a consequence of the differential multiplication of living beings. It has some appearance of purposefulness because it is conditioned by the environment: which organisms reproduce more effectively depends on which variations they possess that are useful in the place and at the time where the organisms live. But natural selection does not anticipate the environments of the future; drastic environmental changes may be insuperable to organisms that were previously thriving. Species extinction is the common outcome of the evolutionary process. The species existing today represent the balance between the origin of new species and their eventual extinction. More than $99 \%$ of all species that ever lived on Earth have become extinct without issue. These may have been more than one billion species; the available inventory of living species has identified and described less than two million out of some ten million or more estimated to be now in existence.

Natural selection does not strive to produce predetermined kinds of organisms, but only organisms that are adapted to their present environments. Which characteristics will be selected depends on which variations happen to be present at a given time in a given place. This, in turn, depends on the random process of mutation (broadly understood), as well as on the previous history of the organisms (i.e., on the genetic make-up they have as a consequence of their previous evolution). Natural selection is an "opportunistic" process. The variables determining in what direction it will go are the environment, the pre-existing constitution of the organisms, and the randomly arising mutations.

Natural selection accounts for the design of organisms, because adaptive variations tend to increase the probability of survival and reproduction of their carriers at the expense of maladaptive, or less adaptive, variations. The arguments of Paley against the incredible improbability of chance accounts of the adaptations of organisms are well taken as far as they go. But neither Paley nor any other author before Darwin, was able to discern that there is a natural process (namely, natural selection) that is not random, but rather is oriented and able to generate order or "create." The traits that organisms acquire in their evolutionary histories are not fortuitous but determined by their functional utility to the organisms, "designed" as it were to serve their life needs.

The process of mutation cannot, by itself, account for adaptation or design. Mutations occur in single individuals; even if a mutation occurs repeatedly in a species consisting of many individuals, it will never extend, not even nearly, to all members of the species because particular mutations will be, over time, counteracted by other mutations and dissolve. Natural selectioni.e., differential multiplication-can accomplish adaptation because a favorable mutation that has occurred in one individual may thus spread to the whole species in a few generations, few in the scale of evolution, and with high probability in the scale of the low probability of mutations.

Chance is, nevertheless, an integral part of the evolutionary process. The mutations that yield the hereditary variations available to natural selection arise at random, independently of whether they are beneficial or harmful to their carriers. This random process (as well as others that come to play in the great theater of life) is counteracted by natural selection, which preserves what is useful and eliminates the harmful. Without mutations, evolution could not happen because there would be no variations that could be differentially conveyed from one to another generation. But without natural selection, the mutation process would yield disorganization and extinction, because most mutations are disadvantageous and occur erratically. Mutation and selection have jointly driven the marvelous process that starting from microscopic organisms has yielded orchids, birds, and humans.

The theory of evolution conveys chance and necessity jointly intricated in the stuff of life; contingency and determinism interlocked in a natural process that has spurted the most complex, diverse, and beautiful entities in the universe: the organisms that populate the earth, including humans who think and love, endowed with free will and creative powers, and able to analyze the process of evolution itself that brought them into existence. This was Darwin's fundamental discovery, that there is a process that is creative though not conscious. And this is the conceptual revolution that Darwin completed: that everything in nature, including the "design" of living organisms, can be accounted for as the result of natural processes governed by natural laws.

\section{References}

Adler, M. 1952. Great books of the western world, Vol. 54, p. 562. Encyclopedia Britannica, Inc., Chicago, IL.

Ahlberg, P.E. and Clack, J.A. 2006. Palaeontology: A firm step from water to land. Nature 440: 747-749.

Avise, J.C. and Ayala, F.J., eds. 2007. In the light of evolution. Volume I: Adaptation and complex design. National Academies Press, Washington, DC.

\section{Genome Research}


Ayala, F.J. 2007. Darwin's gift to science and religion. Joseph Henry Press, Washington, DC.

Barlow, N. 1958. The autobiography of Charles Darwin. Collins, London, UK. Behe, M. 1996. Darwin's black box: The biochemical challenge to evolution. The Free Press, New York.

Cela Conde, C.J. and Ayala, F.J. 2007. Human evolution. Trails from the past. Oxford University Press, Oxford, UK.

Dalton, R. 2006. Feel it in your bones. Nature 440: 1100-1101.

Darwin, C.R. 1859a. On the origin of the species. ch. IX-XIII. John Murray, London, UK.

Darwin, C.R. 1859b. On the origin of the species. pp. 489-490. John Murray, London, UK.

Darwin, C.R. 1859c. On the origin of the species. p. 81. John Murray, London, UK.

Darwin, C.R. 1859d. On the origin of the species. p. 306. John Murray, London, UK
Dembski, W. 1995. The design inference. Eliminating chance through small probabilities. Cambridge University Press, Cambridge, UK.

Dobzhansky, T. 1973. Nothing in biology makes sense except in the light of evolution. Am. Biol. Teach. 35: 125-129.

Eldredge, N. 2005. Darwin. Norton, New York.

Johnson, P. 2000. The wedge of truth. InterVarsity Press, Downers Grove, IL.

Muller, H.J. 1959. One hundred years without Darwin are enough. Sch. Sci. Math. 59: 304-305.

Paley, W. 1802a. Natural theology. R. Fauldner, London, UK.

Paley, W. 1802b. Natural theology. pp. 15-16. R. Fauldner, London, UK.

Wallace, A.R. 1858. On the tendency of varieties to depart indefinitely from the original type. J. Proc. Linnean Society (Zoology) 3: 53-62.

White, T.D., WoldeGabriel, G., Asfaw, B., Ambrose, S., Beyene, Y., Bernor, R.L., Boisserie, J.-R., Currie, B., Gilbert, H., Haile-Selassie, Y., et al. 2006. Asa Issie, Aramis and the origin of Australopithecus. Nature 440: 883889. 


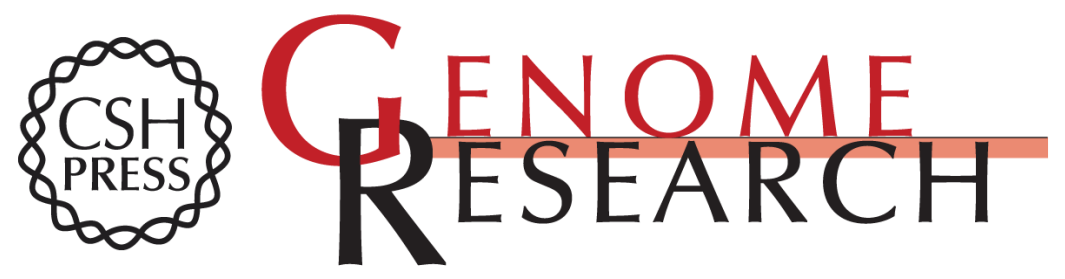

\section{One hundred fifty years without Darwin are enough!}

Francisco J. Ayala

Genome Res. 2009 19: 693-699

Access the most recent version at doi:10.1101/gr.084285.108

References This article cites 7 articles, 1 of which can be accessed free at:

http://genome.cshlp.org/content/19/5/693.full.html\#ref-list-1

\section{License}

Email Alerting Receive free email alerts when new articles cite this article - sign up in the box at the Service top right corner of the article or click here.

\section{Affordable, Accurate Sequencing.}

To subscribe to Genome Research go to: https://genome.cshlp.org/subscriptions 